\title{
The Development of Performers' Rights in New Zealand: Lessons for the Asian Pacific Region?
}

\author{
Jessica C Lai ${ }^{1}$
}

\section{Introduction}

Performers' rights have never been in the limelight in New Zealand. In fact, it is probably safe to say that performers rights have generally taken a backseat to authors' rights in the Asian Pacific region. This is illustrated by the fact that the Asian Pacific Copyright Code makes very little reference to performers and, even then, only in a perfunctory manner. ${ }^{2}$ As discussed in this chapter, the historical notion of the 'lowly performer' next to the idea of the 'romantic author' contributed towards this. At the same time, New Zealand and several Asian Pacific nations are under pressure to increase protections for performers as a result of international trade agreements. However, little scholarship in New Zealand or the Asian Pacific has addressed the nature or impact of performers' rights visà-vis authors' rights, whether from a theoretical, practical or empirical perspective. This chapter analyses the potential expansion of performer's

1 Copyright (C) 2018 Jessica C Lai. Senior Lecturer, School of Accounting and Commercial Law, Victoria University of Wellington. General Secretary of the Asian Pacific Copyright Association.

2 Adrian Sterling 'Asian Pacific Copyright Code' in this volume at C.2, D.1 and E.2. 
rights, arguing that the expansion is either unnecessary because of the growing reach of copyright, or can have little practical effect (or perhaps the wrong effect, depending on one's policy aims) if done incorrectly.

Being a common-law country, New Zealand intellectual property law is predominantly grounded in utilitarian and law and economics philosophies, which do not lend themselves to cultivating performers' rights. ${ }^{3}$ In comparison, natural rights theory still holds powerful sway over France, for example, ${ }^{4}$ which has a strong and history-laden droits des artistes-interprètes. ${ }^{5}$ In New Zealand, there has never been a case on performers' rights and very little has been written about them. ${ }^{6}$ At the time of writing, New Zealand was neither a member of the Rome Convention (for the Protection of Performers, Producers of Phonograms and Broadcasting Organizations) ${ }^{7}$ nor the World Intellectual Property

3 During the Industrial Revolution (1760-1840), Lockean labour theory (a natural rights theory) was used in England to justify property rights in literary works. However, by the mid-19th century, Lockean theory had given way to utilitarianism and consequentialist thinking, bringing patent law into the Modern Era. Though natural rights theory is still used today to justify the protection of intellectual property rights, we tend to focus less on the mental labour or creativity of works/ inventions in order to justify property rights and instead look at the value of the immaterial thing itself with respect to economic or quasi-economic perspectives. See Brad Sherman and Lionel Bently The Making of Modern Intellectual Property Law: The British Experience, 1760-1911 (Cambridge University Press, Cambridge, 1999) at 23-24 and 173-176. Note: certain interpretations of Lockean labour theory hold it as an instrumentalist or consequentialist theory; Justin Hughes 'The Philosophy of Intellectual Property' (1988) 77 Geo LJ 287 at 305-306.

4 In Continental Europe, copyright protection was and continues to be grounded in Kantian and Hegelian natural rights theories related to personality and individuality. See Immanuel Kant 'On the Injustice of Counterfeiting Books' in JAL Sterling World Copyright Law (2nd ed, Sweet \& Maxwell, London, 2003); Georg Wilhelm Friedrich Hegel Grundlinien der Philosophie des Rechts (F. Meiner, Leipzig, 1911) (translated ed: Thomas M Knox (translator) Philosophy of Right (Oxford University Press, Oxford, 1967)).

5 Translation: Performers' rights - see Code de la Propriété Intellectuelle 1992 (France) (as at 10 April 2017), arts L212-1-L212-15.

6 One finds only two pages on performers' rights in Susy Frankel Intellectual Property in New Zealand (2nd ed, LexisNexis, Wellington, 2011) at 313-314. See Intellectual Property Law (online loose-leaf ed, LexisNexis) at [COP169]-[COP170], for a discussion on Part IX of the Copyright Act 1994, which deals with performers' rights; Owen Morgan 'Appendix C Performers' Rights' in Intellectual Property Law (online loose-leaf ed, LexisNexis) at [2120]-[2124] also deals specifically with performers' rights and offers a short overview of the development of performers' rights in New Zealand up to and including the Copyright Act 1994. However, both rely almost exclusively on case law from the United Kingdom, or case law from New Zealand dealing with similar terms used in copyright. The reliance on United Kingdom case law arises because Part IX of the Copyright Act 1994 is based significantly on Part II of the Copyright, Designs and Patents Act 1988 (UK) [CDPA 1988] (as originally enacted), though there are differences.

7 International Convention for the Protection of Performers, Producers of Phonograms and Broadcasting Organizations 496 UNTS 43 (adopted 26 October 1961, entered into force 18 May 1964) [Rome Convention]. 
Organization (WIPO) Performances and Phonograms Treaty (WPPT). ${ }^{8}$ Indeed, New Zealand did not have any protection of performers' rights until the Copyright Act 1994, ${ }^{9}$ when it implemented a weak form of performers' rights as neighbouring rights. ${ }^{10}$ In other words, a 'performance' is not a copyright work, but performances are attributed a kind of protection, different from that conferred upon authors. It is clear that the implementation of performers' rights in 1994 only came about as a consequence of New Zealand's ratification of the World Trade Organization (WTO) Agreement on Trade-Related Aspects of Intellectual Property Rights (TRIPS). ${ }^{11}$ Like the Rome Convention and WPPT, TRIPS predominantly deals with phonograms or sound recordings, ${ }^{12}$ and not audiovisual works or films. ${ }^{13}$ While attempts to create an agreement on audiovisual works eventually led to the signing of the WIPO Beijing Treaty on Audiovisual Works in 2012, ${ }^{14}$ very few countries have ratified this Treaty and New Zealand is not a signatory. ${ }^{15}$ That is to say, New Zealand has no international obligations relating to visual performances. Nevertheless, when New Zealand implemented the

8 WIPO Performances and Phonograms Treaty 2186 UNTS 203 (adopted 20 December 1996, entered into force 20 May 2002) [WPPT]. For a treatise on the development of international performers' rights generally, see Owen Morgan International Protection of Performers' Rights (Hart Publishing, Portland, 2002).

9 Performers' rights had been discussed in New Zealand before this, but there was never any particular drive or persuasive arguments for New Zealand to adopt performers' rights. See Dalglish Committee Report of the Copyright Committee (1959) at 125-127; Department of Justice Reform of the Copyright Act 1962 - A Discussion Paper (1985) at 22; and Department of Justice The Copyright Act 1962 - Options for Reform (1989) at 33-36.

10 With respect to performers' rights, the Copyright Act 1994 significantly mirrored the CDPA 1988 (UK), which was shortly modified by the Copyright and Related Rights Regulations 1996, s 20, to introduce a right to equitable remuneration (discussed below).

11 Agreement on Trade-Related Aspects of Intellectual Property Rights 1869 UNTS 299 (adopted 15 April 1994, entered into force 1 January 1995) [TRIPS]. See Ministry of Economic Development (MED) Performers' Rights: A Discussion Paper (July 2001) at [30]. The MED is now part of the Ministry of Business, Innovation and Employment (MBIE).

12 The terms phonograms and sound recordings traditionally have different meanings, with phonograms tending to relate to the civil-law neighbouring rights system, whereas 'sound recordings' usually refers to the common-law copyright-integrated protection. See Daniel J Gervais The TRIPS Agreement: Drafting History and Analysis (4th ed, Sweet \& Maxwell, Croydon, 2012) at [2.201]. The terms are used interchangeably in this article.

13 As the name suggests, audiovisual works can comprise both the visual and aural components of a recording, though they may only contain the former; see Beijing Treaty on Audiovisual Works (adopted 24 June 2012), art 2(b) [Beijing Treaty]. In comparison, a film only refers to the visual component; see Copyright Act 1994 (NZ), s 2(1), which defines 'film' as 'a recording on any medium from which a moving image may by any means be produced'.

14 Beijing Treaty, above $\mathrm{n} 13$.

15 Of the Asian Pacific, only China and South Korea signed and ratified the Beijing Treaty, while Japan and Russia did not sign the treaty but acceded to it. 
TRIPS Agreement ${ }^{16}$ it did not discriminate between performers of sound recordings and performers in films, ${ }^{17}$ instead extending the rights to both types of performers.

The Ministry of Economic Development (MED) reviewed performers' rights in 2001 and confirmed that there has been little discussion of the rights of performers in New Zealand, and these rights are not well understood'. ${ }^{18}$ The MED released a Discussion Paper on performers' rights, raising a myriad of questions to consider. However, it received few submissions (21), and this outcome was interpreted as suggesting 'New Zealand's performers' rights regime [was] neither well understood nor utilised in performance-based industries'. ${ }^{19}$ The outcome was essentially a recommendation that nothing be changed. ${ }^{20}$ The MED did, however, advise that performers' rights be re-reviewed in the future. ${ }^{21}$ At the time of writing, this review has not taken place. However, when the Comprehensive and Progressive Agreement for Trans-Pacific Partnership (CPTPP) $)^{22}$ comes into force, ${ }^{23}$ New Zealand will have to modify its performers' rights, including the implementation of the WPPT (but not the Rome Convention or Beijing Treaty). ${ }^{24}$ With respect to performers' rights, the CPTPP is more or less identical to its predecessor, the Trans-Pacific Partnership (TPP), except that New Zealand will not have to extend the protection period from 50 to 70 years. ${ }^{25}$

16 Via the enactment of the Copyright Act 1994.

17 The Copyright Act 1994, s 2 defines a film as 'a recording on any medium from which a moving image may by any means be produced', and a sound recording as '(a) a recording of sounds, from which the sounds may be reproduced; or (b) a recording of the whole or any part of a literary, dramatic, or musical work, from which sounds reproducing the work or part may be produced,regardless of the medium on which the recording is made or the method by which the sounds are reproduced or produced'.

18 MED, above $\mathrm{n} 11$, at [2].

19 Office of the Associate Minister of Commerce Performers' Rights Review (2001) at [12].

20 At [1].

21 At [6].

22 Comprehensive and Progressive Agreement for Trans-Pacific Partnership (signed 8 March 2018, not yet in force) [CPTPP]. The official signed version is not yet public. The CPTPP developed from the Trans-Pacific Partnership Agreement (signed 4 February 2016) [TPP]. All the provisions relating to the substantive performers' rights remain in place, except term of protection (art 18.63 was suspended).

23 CPTPP, above n 22, art 30.5.

24 CPTPP, above n 22, art 18.8.2(f); Rome Convention, above n 7; Beijing Treaty, above n 13.

25 See above $\mathrm{n} 22$. New Zealand will have to amend its ratifying legislation accordingly; Trans-Pacific Partnership Agreement Amendment Act 2016, s 28 (replacing s 193) [TPP Agreement Amendment Act]. The WPPT, above $\mathrm{n} 8$, art 17, only requires 50 years of protection for performers' rights. 
On 8 April 2016, the Ministry of Business, Innovation and Employment's (MBIE; successor to the MED) released a Regulatory Impact Statement (RIS) regarding the implementation of the intellectual property chapter of the TPP Agreement. ${ }^{26}$ While the RIS did not discuss all aspects of the TPP intellectual property chapter, it included a section on performers' rights. Following this, the TPP Agreement Amendment Bill was introduced on 9 May 2016. ${ }^{27}$ Rather conspicuously, no mention was made of performers' rights during the Bill's first reading. ${ }^{28}$ The Foreign Affairs, Defence and Trade Committee examined the Bill and reported back on it on 27 October 2016 (TPP Agreement Amendment Bill 133-2). ${ }^{29}$ The Committee did not comment on performers' rights and the substantive clauses remain unchanged, despite the fact that 11 of the 85 submissions made on the Bill provided comments on the performers' rights. ${ }^{30}$ Within the first half of November 2016, the Bill swiftly passed its second reading, went through the Committee of the Whole House and had its third and final reading, ${ }^{31}$ with virtually no mention of performers' rights.

Generally, the Copyright Act 1994 does not distinguish between sound recordings and films. ${ }^{32}$ The TPP Agreement Amendment Act 2016, however, does, introducing 'stronger' rights for sound recordings but not for films. ${ }^{33}$ The legislature only applied the new rights to sound recording to minimise the effect of implementing the TPP and WPPT. ${ }^{34}$ The TPP Agreement Amendment Act 2016 also introduces moral rights for sound recordings and films, but more extensively for the former. ${ }^{35}$ The Act will

26 MBIE Regulatory Impact Statement: Analysis of Options Relating to Implementation of Certain Intellectual Property Obligations under the Trans-Pacific Partnership Agreement (8 April 2016) [MBIE RIS].

27 Trans-Pacific Partnership Agreement Amendment Bill 2016 (133-3).

28 (12 May 2016) 713 NZPD 11059.

29 See Ministry of Foreign Affairs and Trade (MFAT) Trans-Pacific Partnership Agreement Amendment Bill: Departmental Report for the Foreign Affairs, Defence and Trade Committee (MFAT, September 2016) [MFAT Departmental Report].

30 MFAT Departmental Report, above n 29, Annex A at 67-78. The 11 submissions were from: The Electronic Frontier Foundation; The International Association of Music Libraries (NZ); Mr Jobson; Legislation Design and Advisory Committee; Library and Information Association of New Zealand Aotearoa; MBIE; New Zealand Institute of Patent Attorneys; New Zealand Law Society; Recorded Music, APRA AMCOS, Independent Music New Zealand, The New Zealand Music Commission, and The Music Managers Forum; Te Whakakitenga o Waikato Inc; and Universities New Zealand.

31 On: (3 November 2016) 718 NZPD 14756; (8 November 2016) 718 NZPD 14839; and (10 November 2016) 718 NZPD 14978 and (15 November 2016) 15044, respectively. The Bill received its Royal Assent on 21 November 2016.

32 Copyright Act 1994.

33 TPP Agreement Amendment Act 2016, s 18.

34 MBIE RIS, above n 26, at [262].

35 TPP Agreement Amendment Act 2016. 
have to be amended in light of differences between the TPP and CPTPP, however the Act's provisions on performers' rights should not change. In all likelihood, any legislative amendments will only come into force if the CPTPP comes into force. ${ }^{36}$

The TPP/CPTPP aside, the proposed changes and issues discussed here are pertinent. First, if New Zealand were ever to achieve an elusive European Union - New Zealand free trade agreement (FTA), ${ }^{37}$ it would in all likelihood require that New Zealand ratify the WPPT. Indeed, the leaked 15 October 2015 version of the Regional Comprehensive Economic Partnership (RCEP) ${ }^{38}$ intellectual property chapter indicates that it would also require New Zealand to ratify the WPPT, as well as the Rome Convention and Beijing Treaty. ${ }^{39} \mathrm{~A}$ majority of the RCEP nations have already ratified the WPPT. ${ }^{40}$ It thus seems that the WPPT performers' rights will be semi-harmonised across much of the Asian Pacific region, whether as a result of some regional attempt to codify copyright and neighbouring rights, or the CPTPP, RCEP or another FTA. This makes the analysis of the impact of ways in which New Zealand would or could implement the WPPT important. Second, even if it were not the case that New Zealand will eventually have to ratify the WPPT, ${ }^{41}$ the broader discussion on the relevance of performers rights in New Zealand (and, indeed, the Asian Pacific region), as they exist or in a 'stronger' form, is important.

As seems the tradition in New Zealand, little has been said about the proposed changes to performers' rights. This chapter does so. The purpose is not to critically analyse current law and the potential changes in detail, but to ask the broader question of the relevance of performers' rights in New Zealand and what it would mean to have 'stronger' rights. Part 2 'sets the scene' by briefly outlining performers' rights under the Copyright

36 As is the case under the TPP Agreement Amendment Act 2016, s 2(2).

37 New Zealand has long sought such an FTA; see MFAT 'New Zealand-European Union FTA' New Zealand Foreign Affairs and Trade www.mfat.govt.nz. The beginning of negotiations for such an agreement was announced on 30 October 2015; John Key 'NZ takes significant step towards an EU FTA' (press release, 30 October 2015).

38 Between Brunei Darussalam, Cambodia, Indonesia, Laos, Malaysia, Myanmar, the Philippines, Singapore, Thailand, Vietnam, Australia, China, India, Japan, South Korea and New Zealand.

39 '2015 Oct 15 version: RCEP IP Chapter' (19 April 2016) Knowledge Ecology International www.keionline.org at arts 1.7.6(f) and (h)-(i); WPPT, above n 8; Rome Convention, above n 7; Beijing Treaty, above $\mathrm{n} 13$.

40 For example, of the RCEP countries: Brunei Darussalam, Indonesia, Malaysia, Philippines, Singapore, Australia, China, Japan and South Korea.

41 WPPT, above $\mathrm{n} 8$. 
Act 1994 and what changes could be introduced if New Zealand has to implement the WPPT. ${ }^{42}$ Part 3 assesses performers and performances in contradistinction to authors and works from a theoretical perspective, examining whether it makes sense that copyright law holds the 'romantic author' in higher esteem than the 'lowly performer'. The chapter then looks at the actual situation in New Zealand from different perspectives, to address the significance of performers' rights and the need for, and potential effects of, introducing 'stronger' rights (as would be required by the implementation of WPPT). It asks whether introducing 'stronger' rights would improve the position of performers in reality.

\section{Performers' Rights in New Zealand}

Presently, New Zealand has only minimal protection of performers' rights. ${ }^{43}$ Performers only have personal rights for economic rights (rather than property rights ${ }^{44}$ and have no moral rights. New Zealand law does go beyond its TRIPS obligations by protecting performers of sound recordings and films, where TRIPS only requires the former. There are two kinds of economic performers' rights: primary and secondary.

\subsection{Primary Economic Rights}

Primary rights relate to a live performance itself, namely its recording, broadcast or communication to the public, rather than to a recording of a performance or a copy thereof. The Copyright Act 1994 states that any performers' rights are infringed if someone records (meaning in a sound recording or film $)^{45}$ the whole or a substantial part of a performance, ${ }^{46}$ without consent. ${ }^{47}$

42 Copyright Act 1994; WPPT, above n 8.

43 The Copyright Act 1994 does not define 'performer', but 'performance'; Copyright Act 1994, s 169 (a).

44 Performers also cannot assign away their rights, though they can be passed by testamentary disposition; Copyright Act 1994, s 194.

45 Section 169.

46 Section 169.

47 Section 171(1)(a). Compare CDPA 1988 (UK), s 182(1)(a). 
The Copyright Act 1994 additionally makes it an infringement of a performer's rights to communicate live to the public the whole or any substantial part of a performance, without consent. ${ }^{48}$ The right to 'communicate to the public' is defined broadly under the Copyright Act 1994, as 'communicate means to transmit or make available by means of a communication technology, including by means of a telecommunications system'. ${ }^{49}$ It thus includes what international law calls broadcasting, communication to the public and also making available to the public.

The TPP Agreement Amendment Act 2016 would not make any changes to the primary economic rights. ${ }^{50}$

\subsection{Secondary Economic Rights}

Secondary rights pertain to the exploitation of a recording or copy thereof. Sections 172-174 of the Copyright Act 1994 state that it is an infringement of performers' rights to use a (sound or film) recording of a performance without consent in the following ways: ${ }^{51}$

- To show in public, play in public, communicate to the public the whole or a substantial part of a performance, if the recording was made without the performer's consent, and the user knew or had reason to believe that there was no consent. ${ }^{52}$

- To copy a recording, if the user knew or had reason to believe that the recording was made without consent. ${ }^{53}$

- To copy a recording for a purpose other than that for which the performer gave consent to the recording. ${ }^{54}$

- To copy a recording that was made in accordance with an exemption under ss $175-179$ or 181-191 for a different purpose. ${ }^{55}$

- To import a recording that the importer knows or has reason to believe is an illicit recording. ${ }^{56}$

48 Copyright Act 1994, s 171(1)(b). Compare CDPA 1988 (UK), s 182(1)(b).

49 Copyright Act 1994, s 2.

50 TPP Agreement Amendment Act 2016.

51 Copyright Act 1994, ss 172-174; Note: Morgan has stated that there is problem with the secondary rights in the Copyright Act 1994 because performance is defined as 'live performance' and it is not possible to do the infringing acts with a live performance; Morgan, above n 6, at Appendix C [2133]. However, he is clearly mistaken, as ss $172-174$ pertain to recordings of performances.

52 Copyright Act 1994, s 172. Compare CDPA 1988 (UK), s 183.

53 Copyright Act 1994, s 173(1).

54 Section $173(3)(\mathrm{a})$.

55 Section 173(3)(B)

56 Section 174(1)(a). Compare CDPA 1988 (UK), s 184(1)(a). 
- In the course of business, to possess, sell, let for hire, offer or expose for sale or hire, or distribute, a recording that the importer knows or has reason to believe is an illicit recording. ${ }^{57}$

It is these rights that will be affected if New Zealand has to implement the WPPT. ${ }^{58}$ The WPPT specifically requires that performers of phonograms have the exclusive right to authorise:

- the direct or indirect reproduction; ${ }^{59}$

- the distribution (making available of the 'original and copies') 'through sale or other transfer of ownership'; 60

- the commercial rental of the 'original and copies'; ${ }^{61}$

- the making available, by wire or wireless means, 'in such a way that members of the public may access them from a place and at a time individually chosen by them'. ${ }^{62}$

These are positively phrased and transferable, ${ }^{63}$ and are, thus, property rights.

The TPP Agreement Amendment Act 2016 retains the status quo for films. It introduces a new set of property rights for the secondary economic rights for sound recordings, as displayed in Table 1.

57 Copyright Act 1994, s 174(1)(b). Compare CDPA 1988 (UK), s 184(1)(b).

58 WPPT, above $\mathrm{n} 8$; If the TPP comes into force, New Zealand will have to amend the Copyright Act 1994 to meet WPPT standards. See CPTPP, above n 22, arts 18.58, 18.60 and 18.62.3(a). See also the art 18.57 definitions of 'broadcasting' and 'communication to the public'.

59 WPPT, above $\mathrm{n} 8$, art 7.

60 Article 8. An open (and highly controversial) question remains whether distribution is only for tangible copies of performances, or includes digital distribution.

61 WPPT, above n 8 , art 9.

62 WPPT, above $\mathrm{n} 8$, art 10 . Article 15 also includes a right to a single equitable remuneration 'the direct or indirect use of phonograms published for commercial purposes for broadcasting or for any communication to the public'. However, subarticle 3 allows countries to opt out of the right. The right is not specifically required by the CPTPP, above n 22 . New Zealand has not implemented art 15 of the WPPT, above $\mathrm{n}$ 8, in the TPP Agreement Amendment Act 2016. This is consistent with the MED's statement that 'a right of remuneration would represent an additional cost that is likely to be passed on to the consumer. A remuneration right also leads to an outflow of moneys in a country like New Zealand, which is a net importer of performances. The outflow will occur because overseas performers will be entitled to be remunerated in New Zealand alongside domestic performers. Although there will be some money flowing into New Zealand from New Zealand performances exploited in other countries, it is unlikely to be enough to balance the outflow'. See MED, above n 12, at [109].

63 The WPPT does not explicitly state that these rights are transferable, above $\mathrm{n} 8$. However, art 5(1) states that moral rights stay with performers even upon the transfer of their economic rights, implying that economic rights are transferable. 
Table 1. Possible Implementation of the WPPT.

\begin{tabular}{|l|l|l|}
\hline WPPT Right & TPP Agreement Amendment Act 2016' & $\begin{array}{l}\text { Amendment to the } \\
\text { Copyright Act 1994² }\end{array}$ \\
\hline Reproduction & Copying & S 174C \\
\hline Distribution & Issuing copies to the public & s 174D \\
\hline Rental right & Issuing copies to the public & s 174D \\
\hline Making available & Communicate to the public & s 174B \\
\hline
\end{tabular}

${ }^{1}$ TPP Agreement Amendment Act 2016, s 24.

${ }^{2}$ Copyright Act 1994.

Source: Author's summary.

As noted above, 'communicate to the public' includes making available to the public in New Zealand. ${ }^{64}$ As defined in the Copyright Act 1994, 'issuing copies to the public' includes distribution and rental. ${ }^{65}$ The TPP Agreement Amendment Act 2016 states that the economic rights of performers of sound recordings (but not films) are 'personal or moveable property' rights and states that performers can assign their rights, or dispose of them by testament, and exclusively licence them. ${ }^{66}$ The 2016 Act specifically stipulates performers' secondary rights in films would remain personal rights. ${ }^{67}$

New Zealand chose to differentiate between films and sound recordings with respect to the new introduced property rights in order to minimise the impact of its TPP obligations. ${ }^{68}$ However, the differentiation demonstrates a hierarchy of value of performers, with performers of sound recordings sitting higher than performers of films, which one also observes at the international level where the WPPT enjoys more status and acceptance compared to the Beijing Treaty. ${ }^{69}$

64 Copyright Act 1994, s 2.

65 Section 9.

66 TPP Agreement Amendment Act 2016, s 29, implementing ss 194E-194K.

67 TPP Agreement Amendment Act 2016, s 29, implementing ss 194C and 194D.

68 CPTPP, above $\mathrm{n} 22$.

69 WPPT, above n 8; Beijing Treaty, above n 13. 


\subsection{Performers' Moral Rights}

Rather unsurprisingly, TRIPS does not require the protection of moral rights of performers; this mirrors the explicit exclusion of authors' moral rights in TRIPS. ${ }^{70} \mathrm{New}$ Zealand also does not protect the moral rights of performers, because moral rights are linked to particular categories of copyright works and a performance is not a work. ${ }^{71}$

The WPPT requires that states protect moral rights of performers, again with respect to performances fixed in phonograms and also live aural performances', namely: $:^{72}$

- the right to claim to be identified as the performer; and

- the right to object to any 'distortion, mutilation or other modification of his performance that would be prejudicial to his reputation'.

The TPP Agreement Amendment Act 2016 contains these two rights. ${ }^{73}$ It grants the right to be identified to both performers in sound recordings and films, but more broadly for the former. ${ }^{74}$ Performers of sound recordings (not films) would also be protected from 'distortion, mutilation, or other modification', in relation to the whole or any part of a performance, ${ }^{75}$ that is 'prejudicial to the honour or reputation of the performer'. ${ }^{76}$

Per the 2016 Act, moral rights would not be assignable, but could be disposed by testament. ${ }^{77}$ The 2016 Act would allow performers to waive their moral rights. ${ }^{78}$ This is not possible in all countries, particularly not in civil-law countries, like France and Germany, which justify their laws on natural rights theory. However, the instrument provided in the 2016 Act to performers to waive their moral rights is analogous to that which allows authors to waive their moral rights, ${ }^{79}$ and is in accordance with an economics theory approach.

70 TRIPS, above n 11, art 9(1).

71 See Copyright Act 1994, s 14(1).

72 WPPT, above n 8, art 5(1).

73 Compare CDPA 1988 (UK), ss 2015C-205H, as amended 1 February 2006 by The Performances (Moral Rights, etc.) Regulations 2006 (SI 2006/18) and 31 October 2003 by The Copyright and Related Rights Regulations 2003 (SI 2003/2498).

74 TPP Agreement Amendment Act 2016, s 18, implementing s 170A.

75 TPP Agreement Amendment Act 2016, s 18, implementing s 170I(2).

76 TPP Agreement Amendment Act 2016, s 18, implementing s 170F.

77 TPP Agreement Amendment Act 2016, s 29, implementing ss 194A and 194B.

78 TPP Agreement Amendment Act 2016, s 18, implementing s 170H.

79 See Copyright Act 1994, s 107(2). 


\section{The Historical 'Lowly Performer'}

Performers' rights exist as neighbouring rights to copyright. In New Zealand, and most (if not all) western countries, performances are not copyright works. ${ }^{80}$ As mere 'conduits' or 'interpreters' of existing literary and musical works, ${ }^{81}$ singers, dancers and actors are not considered to have added any creativity over and above the existing works and, thus, have no separate copyright for their performance. This conceptualisation of the author/composer as having primacy over the performer stems in part from the contraposition of the romantic author and the lowly performer in the 18th and 19th centuries. ${ }^{82}$ Ruth Towse has also suggested that the hierarchy was influenced by the introduction of copyright for composers as authors in the late 19th century, which raised the relative status of composers. ${ }^{83}$ That authors/composers rank higher than performers is also a consequence of the fact (or belief) that copyright works come first; there must be something for a performer to perform. ${ }^{84}$ Andreas Rahmatian discussed this, stating that, while a performance animates a work, it does not create an object of copyright protection because: ${ }^{85}$

the object of protection is already the written piece recorded in a score or recorded on a sound recording as a past musical event: time and the necessary volatility and imprecision which time entails have been removed.

80 See Copyright Act 1994, s 14(1). There is, after all, no property in a spectacle; Victoria Park Racing \& Recreation Grounds Co Ltd v Taylor [1937] HCA 45. Some discussion has been made about whether performers should have copyright; see Department of Justice, The Copyright Act 1962 - Options for Reform, above n 9, at [10.2]-[10.11]; and, in the United Kingdom, Gerald Dworkin 'The Whitford Committee Report on Copyright and Designs Law' (1977) 40(6) MLR 685 at 690-691.

81 The words of songs and the music to those songs are usually separate works. An exception may be rap, where the words cannot be separated from the music. See Brown v Mcasso Music Production Ltd [2005] EWCC 1 (Cpwt) at [6]-[7] and [45]-[46], which held that Mr Brown's changes to lyrics made him a co-author of the literary work of the song 'Mr High Roller'. While Judge Fysh did not go so far as to say that Mr Brown also had copyright in the music, the importance of the lyrics of rap for the overall song contributed to the finding that $\mathrm{Mr}$ Brown was a co-author.

82 Ruth Towse 'The Singer or the Song? Developments in Performers' Rights from the Perspective of a Cultural Economist' (2007) 3 Rev L \& Econ 745 at 746-747.

83 At 748.

84 Notably, it does not seem to be an issue for co-authorship whether contributions occur in series or parallel; see Alison Firth 'Music and Co-Authorship/Co-Ownership' in Andreas Rahmatian (ed) Concepts of Music and Copyright: How Music Perceives Itself and How Copyright Perceives Music (Edward Elgar, Cheltenham, 2015) 143 at 257.

85 Andreas Rahmatian 'The Elements of Music Relevant for Copyright Protection' in Andreas Rahmatian (ed) Concepts of Music and Copyright: How Music Perceives Itself and How Copyright Perceives Music (Edward Elgar, Cheltenham, 2015) 78 at 89. 
Rahmatian, however, noted that this is not always the case and in reality one precipitates the other and they are often inseparable in the creative process, for example in improvisation'. ${ }^{86}$ Thus, while Rahmatian indicated the importance of chronology for copyright law, he also highlighted that copyright cannot take into account the temporal aspect of music and music-making. In the quote above, he also implied that copyright's need for static and definable property prevents us from recognising performances as works, because performances have an inherent temporal character. The allusion to the ephemeral nature of performances leads us to the next point.

It is not always easy to see the contribution made by a performer, ${ }^{87}$ nor can one simply separate a performance from the work that is being performed. ${ }^{88}$ The boundaries of the performance are difficult to define, in contrast to the boundaries of a literary work or musical work. ${ }^{89}$ In explaining why performances are not recognised as works in contrast to the work they are performing, Mathilde Pavis stated that 'the work of the author has clear boundaries'..$^{90}$ While lyrics and compositions may have clearer boundaries than performances, it is arguably incorrect to say that they have clear boundaries. Many questions remain open regarding the delineations of copyright works, for example: when there are several versions (or drafts), ${ }^{91}$ when a work changes depending on the user, ${ }^{92}$ when a work contains something biological or when the work is incomplete, ${ }^{93}$ the line between a musical work and an adaptation, derivative work or substantial rearrangement, ${ }^{94}$ what is functional/utilitarian as opposed to

\footnotetext{
86 At 117.

87 Mathilde Pavis 'Is There Any-Body on Stage? A Legal (Mis)understanding of Performances' (2016) 19 JWIP 99 at 106.

88 Towse, above n 84 , at 752 .

89 Pavis, above n 89, at 106.

90 Pavis, above $\mathrm{n} 89$, at 106.

91 Sweeney v Macmillan Publishers Ltd [2002] RPC 651.

92 For example, video games and Komesaroff $v$ Mickle [1988] RPC 204 (VSC). In Komesaroff $v$ Mickle, the court held that sand and air between two glass planes was not a work of artistic craftsmanship, because the sand landscape resulted from the user not the maker.

93 Kelley v Chicago Park District 635 F 3d 290 (7th Cir 2011); and Massachusetts Museum of Contemporary Art Foundation, Inc v Büchel 593 F 3d 38 (1st Cir 2010). As discussed by Michael J Madison 'Understanding Access to Things: a Knowledge Commons Perspective' in Jessica C Lai and Antoinette Maget Dominicé (eds) Intellectual Property and Access to Im/material Goods (Edward Elgar, Cheltenham, 2016) 17 at 31-38.

94 Rahmatian, above n 86, at 115-116; and Shane O'Connor 'A Critical Evaluation of the Law of Copyright Authorship in Relation to Derivative Musical Works' (2014) 3(2) Westminster L Rev.
} 
expression, ${ }^{95}$ or where the line is between the idea and the expression (including within music). ${ }^{96}$ Indeed, there is a significant discourse regarding the concept and bounds of the musical work. ${ }^{97}$ In any case, given that the existing categories of copyright works are by no means clear-cut, that performances have nebulous boundaries is not a strong reason to find against copyright. ${ }^{98}$

Towse criticised the fact that authors/composers are given primacy over performers, noting that there are far more songs and musical works in existence than will ever be performed, and authors/composers need their works to be performed, otherwise they have little value. ${ }^{99}$ Noting that the chronological chain of events is irrelevant because authors/composers and performers have mutual need for each other, ${ }^{100}$ Towse stated: ${ }^{101}$

incentives to perform must be taken into account if copyright is to achieve its goal of not only stimulating the creation of works but also their publication. The unperformed song has little value either to the composer or to society at large.

Singers and musicians are, after all, the ones that make lyrics and compositions famous. Additionally, Alison Firth has discussed that musical and dramatic works are designed to be performed and that a performance can end up defining the work, particularly when fixation is achieved by recording a performance. ${ }^{102}$

95 For example, Star Athletica, LLC v University Brands, Inc (USSC, Docket No.15-866) regarding whether certain aspects of designs (stripes, chevrons, zigzags and colour blocks) for cheerleading outfits are copyrightable or a functional/utilitarian. In the lower court, the majority of the 6th Circuit held Varsity's designs were distinctive graphic works, separate from the function of the outfits (6th Cir, Docket No. 14-5237, 19 August 2015).

96 Rahmatian, above n 86, at 111-116.

97 See John Butt "What is a "Musical Work"? Reflections on the Origins of the "Work Concept" in Western Art Music' in Andreas Rahmatian (ed) Concepts of Music and Copyright: How Music Perceives Itself and How Copyright Perceives Music (Edward Elgar, Cheltenham, 2015) 1.

98 Patents are arguably also granted for objects that are poorly delineated. See e.g. James Bessen and Michael J Meurer Patent Failure: How Judges, Bureaucrats, and Lawyers Put Innovators at Risk (Princeton University Press, New Jersey, 2008).

99 Towse, above $\mathrm{n} 84$, at 752.

100 At 764.

101 At 752. Note the analogies between this argument and arguments that patent law needs to take into account post-grant incentives to ensure the commercialisation of patented inventions; see Edmund Kitch 'The Nature and Function of the Patent System' (1977) 20(2) JL \& Econ 265; and Ted Sichelman 'Commercializing Patents' (2010) 62 Stan L Rev 341.

102 Firth, above n 86, at 152. See also Dalglish Committee, above n 9, at 125. The definitions of literary, dramatic and musical works in s 2 of the Copyright Act 1994, also make it clear that many works are meant to be performed. 
That copyright law does not recognise the performer as bringing any extra creativity has been challenged as reflecting an outdated philosophy of performance. ${ }^{103}$ Pavis argued that performers can undertake creative choices when interpreting a work and usually enough to satisfy the level of creativity (or originality) required to have copyright, namely 'time, skill and effort' (or skill, judgment and/or labour), a very low standard in New Zealand. ${ }^{104}$ Furthermore, Towse has argued that, purely from a Lockean perspective, a performer should be entitled to a share in the revenue for any value that he/she adds. ${ }^{105}$

To be clear, this is not to say that performers should, thus, have copyright or 'stronger' neighbouring rights (as would be introduced by the TPP Agreement Amendment Act 2016), ${ }^{106}$ but to refute the notion that the 'romantic author' necessarily sits higher on the creative scale (and consequently also the value scale) than the 'lowly performer'. Nevertheless, while lyrics are literary works, screenplays are dramatic works, compositions are musical works, and sound recordings and films are works in themselves, each with authors (including producers and directors for sound recordings and films, respectively), performances are not works and performers do not have copyright for their performances. As discussed further below, performers might nevertheless be authors (Part 4.3). This is not just because they are often also composers, lyricists, screenplay writers or choreographers, but because their performances may have certain aspects that qualify as part of copyright works.

103 See Pavis, above n 89; and Aurore Vinant, 'Le danseur, interprète et/ou auteur?' (2014) 2 Recherches en danse 1. Compare Phillip Johnson and Sheldon W Halpern 'When is a Performance not a Performance (but a Copyright Work)?' (2014) 4(3) QMJIP 236, which discusses Garcia $v$ Google 743 F 3d 1258 (9th Cir 2014) - a case where the majority found that a performance was a separate copyright right. But see Conrad v AM Community Credit Union, case no 13-2896 (7th Cir 2014), which held that an actress' performance was not a copyright work. Notably, the disconnect between copyright law and philosophy on the role of the author is also dated and we are stuck on the notion of the romantic author; see Lionel Bently 'Copyright and the Death of the Author in Literature and the Law' (1994) 57 MLR 973. Compare Martin Parker Dixon 'Creativity and Possessive Interests' in Andreas Rahmatian (ed) Concepts of Music and Copyright: How Music Perceives Itself and How Copyright Perceives Music (Edward Elgar, Cheltenham, 2015) 50 at 66 who states that it is 'sheer hubris' to remove authors and artists from the equation.

104 The latter is the test in New Zealand, per Ladbroke $v$ William [1964] 1 All ER 465 (HL). See also Henkel $v$ Holdfast NZ Ltd [2007] 1 NZLR 577 at [38] per Tipping J, confirming that the threshold for originality is low in New Zealand and looks at 'how much skill and labour has gone into its creation'. See also University of London Press Ltd v University Tutorial Press Ltd [1916] Ch at 608-609 per Peterson J, stating that originality 'does not require that the expression be in an original or novel form, but that the work must not be copied from another work - that it should originate from the author'.

105 Towse, above n 84, at 754 .

106 TPP Agreement Amendment Act 2016. 
Performers' rights differ from classical copyright because they are not for a work, but for a particular performance. As alluded to above, performances have been argued to be ephemeral, lacking in tangibility or materiality, ${ }^{107}$ and this is confirmed by the fact that a performance of a work is not a fixation of it; the performance would have to be recorded and then there would be fixation of the underlying works. However, in a way, performers' rights relate to something far less abstract than classical copyright works. This is because performers' rights relate to a specific embodiment of a work. Another person can re-enact the performance, copy the intonation, pitch, syncopation and pausing, ${ }^{108}$ for example, but will not be infringing performers' rights (though perhaps copyright in any underlying works) unless they use or copy the actual embodiment or performance. This is analogous with films and sound recordings (modern categories of copyright works), ${ }^{109}$ which are also less abstract as they protect a particular embodiment of underlying works. ${ }^{110}$

\section{Do Performers' Rights Matter?}

While performers might be just as deserving of rights as authors, being equally as creative and playing a pivotal role on the dissemination of authors works, this is not to say that existing performers rights in the Copyright Act 1994, or the 'stronger' rights proposed in the TPP Agreement Amendment Act 2016, necessarily create the best environment for performative creativity. ${ }^{111}$ Indeed, performers' rights are perhaps, by and large, of little practical importance in New Zealand because:

- Performers' rights have been largely ignored by government, practitioners, academics and performers themselves.

- Common-law countries have been relatively apathetic to performers' rights and moral rights generally.

- Performers potentially have copyright as authors if they modify the underlying works enough to qualify for a new work.

- Contract law dominates any intellectual property.

107 As discussed by Pavis, above n 89, at 107.

108 See Elizabeth Coffey $v$ Warner/Chappell Music Ltd [2006] EWHC 449 (Ch) at [5]-[6].

109 In New Zealand, the Copyright Act 1962, s 7, only covered literary, dramatic, musical, and artistic works. The Copyright Act 1994, s 14(1), introduced both 'films' and 'sound recordings' as categories of works.

110 Indeed, one could view a sound recording or film as an embodiment of an embodiment of a work.

111 Copyright Act 1994; TPP Agreement Amendment Act 2016. 
The questionable importance of performers' rights in New Zealand will be expanded upon here.

\subsection{Perceived Relevance for New Zealand}

Arguments for 'stronger' performers' rights are analogous to those for authors' rights; namely, that exclusive rights are required to offer extrinsic incentives for creativity. ${ }^{112}$ Similarly, reasons against performers' rights are also the same as those against authors' rights; in particular, that performers - like authors and artists - have other intrinsic incentives to create. Additionally, just as authors' (and publishers') rights emerged after the invention of the printing press and separation of an author from his or her work, ${ }^{113}$ performers' rights arose in Europe with the development of recording technologies, and then broadcasting technologies, and the separation of performers from - and replacement of performers with their performances. ${ }^{114}$ In either case, the creative parties were concerned with the unauthorised fixation of their works and the use of those fixations.

A noted above, New Zealand only introduced performers' rights because it had to under its TRIPS obligations. ${ }^{15}$ If one looks at the historical discussion on performers' rights in New Zealand, there has never been a local push for the introduction or expansion of performers' rights. In 1959, the Report of the Copyright Committee stated: ${ }^{116}$

There is reason to believe that these problems [as in Europe], such as the threat to the livelihood of musicians, do not exist to anything like the same extent in New Zealand. There are few full-time professional musicians in this country and it is probable that the growth of radio, in particular, far from harming musicians, has given them an audience which they would not otherwise have had.

In 1989, the Law Reform Division of the Department of Justice noted that there did not appear to be any need to protect performers' rights, as there was 'no evidence that unauthorised fixation of performances

112 For example, Office of the Associate Minister of Commerce, above n 19, at [7].

113 See William Cornish 'Conserving Culture and Copyright: A Partial History' (2009) 13(1) Edin L Rev 8.

114 Morgan, above n 8, at 54-59; and Towse, above n 84, at 748; and John Williamson 'For the Benefit of All Musicians? The Musicians' Union and Performers' Rights in the UK' in Andreas Rahmatian (ed) Concepts of Music and Copyright: How Music Perceives Itself and How Copyright Perceives Music (Edward Elgar, Cheltenham, 2015) 167 at 181-182.

115 TRIPS, above n 11.

116 Dalglish Committee, above n 9, at 126. 
constitute[d] a problem in New Zealand'. ${ }^{117}$ In its 2001 Discussion Paper, the MED acknowledged that New Zealand only had performers' rights because of its international obligations and not due to any theoretical (whether economic- or natural rights-based) justifications. ${ }^{118}$ Indeed it noted that, with respect to performers' rights, the economic incentive argument was weak because performers in New Zealand had very little knowledge about their rights, such that the rights could not constitute any kind of incentive to perform. ${ }^{119} \mathrm{New}$ Zealand nevertheless has burgeoning music and film industries. Arguably, other legal regimes hold far greater sway over the film industry, such as tax and employment law. Moreover, in light of the fact that featured singers and musicians may in fact have copyright if they modify any underlying work to a sufficient extent to be original (as discussed below, part 4.3), certain performers arguably already have enough of an incentive.

Indeed, creative industries have strong non-economic incentives, such as the drive for self-expression, communication, respect from one's peers and 'fame', or the pursuit of 'art for art's sake'. ${ }^{120}$ There is a compelling argument to be made that inappropriately offering extrinsic rewards for activities that are primarily motivated by intrinsic grounds can have a 'crowding out effect' and either fail as an incentive or even act as a disincentive. ${ }^{121}$ That is, offering extrinsic rewards where intrinsic motivations pre-exist can crowd out or remove those intrinsic motivations, potentially forever, and can even discourage the behaviour it is meant to incentivise. ${ }^{122}$

117 Department of Justice, The Copyright Act 1962 - Options for Reform, above n 9, at [10.11].

118 MED, above n 11, at [16]-[17].

119 MED, above n 11, at [16]. See also Dalglish Committee, above n 9, at 126, which noted that 'there appears to be no demand for it in New Zealand by performers themselves'.

120 See Jiarui Liu 'Copyright for Blockheads: An Empirical Study of Market Incentive and Intrinsic Motivation' (2010) 38(4) Colum JL \& Arts 467; and Jessica Silbey The Eureka Myth: Creators, Innovators, and Everyday Intellectual Property (Stanford University Press, Stanford, 2014). Note that similar arguments are made regarding non-economic reasons to invent in the patent law discourse, such as the prestige associated with invention (possibly the opportunity for co-authorship), altruistic desires (to 'save the world') and the chance to participate in the advancement of science. See Yochai Benkler 'Commons-Based Strategies and the Problems of Patents' (2004) 305 Science 1110 at 1111; and Robin Feldman 'The Open Source Biotechnology Movement: Is it Patent Misuse?' (2004) 6(1) Minn JL Sci \& Tech 117 at 161.

121 Bruno S Frey and Reto Jegen, 'Motivation Crowding Out' (2001) 15(5) J Econ Surv 589 at $589-591$.

122 See also Bruno S Frey 'Crowding Out and Crowding In of Intrinsic Preferences' in Eric Brousseau, Tom Dedeurwaerdere and Bernd Siebenhüner (eds) Reflexive Governance for Global Public Goods (Massachusetts Institute of Technology, Massachusetts, 2012) 75; Bruno S Frey and Felix Oberholzer-Gee 'The Cost of Price Incentives: An Empirical Analysis of Motivation Crowding-Out' (1997) 87(4) Am Econ Rev 746; and more broadly Bruno S Frey Arts and Economics (Springer, Heidelberg, 2000). 
Moreover, other initiatives supporting the arts may prove to be better promoters of creativity than property or property-like rights. ${ }^{123}$ There is no concrete evidence that copyright and neighbouring rights are the ideal means to offer extrinsic rewards and not, for example, prizes, direct state subsidies, ${ }^{124}$ or public/private patronage. This is not to say that extrinsic rewards have no role in the creative sector, but rather that the picture is complex and we have to be careful about the type and extent of extrinsic rewards we put forward.

As with patents and copyright, it is arguable that financial or economic incentives are only required for employers, investors or right holders, rather than inventors, authors or performers. Much invention occurs in the absence of patents, for example, by researchers in universities and publicly funded organisations, but pharmaceutical companies are heavily reliant on patents. At the same time, while songwriters and authors might be incentivised by intrinsic motivations, music producers and book publishers are less likely to invest in commercialisation in the absence of intellectual property protection. Analogously, it is music producers that are more susceptible to incentives created by copyright and related rights, as opposed to performers. This is, of course, a simplistic view, based on generalisations. The role of patents varies across differing industries. For example, motivations in the software industry are not the same as those in the pharmaceutical industry. Equally, there are authors and artists who are motivated by economic incentives, and there are music producers and book publishers that do not seek to profit. However, the general point is that incentive arguments for 'stronger' performers' rights are arguably weak.

In 2001, the MED stated that, as a net importer of performances, an extension of performers' rights would predominantly benefit foreign and not local - performers, and would lead to a net outflow of royalties from New Zealand. ${ }^{125}$ It is difficult to see how this is the case when there is no right to remuneration. How much foreign performers get depends on their contracts with their producers. Normally, they would contract to allow their producers to reproduce their performances and distribute copies, internationally. Even if their contracts stipulate that they receive

123 Office of the Associate Minister of Commerce, above n 19, at [42]-[43].

124 Copyright and neighbouring rights are a form of indirect subsidies, as are state-funded music or drama schools or faculties at universities and colleges.

125 MED, above n 11, at [26]. 
a certain royalty for each public performance or communication, or each copy made or sold, this has (almost) nothing to do with New Zealand's law on performers' rights. It is a matter of contract law and, as noted, the terms of contract are usually stipulated to be international to simplify matters.

This position is supported by the statement made by the Ministry of Foreign Affairs and Trade (MFAT) in January 2016 that: ${ }^{126}$

Giving performers new rights is unlikely to incentivise an increase in the number of performances, an increase in the number of sound recordings created from performances, or in the distribution and sale of sound recordings in the New Zealand market. The New Zealand market is a small market by world standards. Most performers are therefore likely to base their production and distribution decisions on the conditions in large overseas markets like the US and Europe rather than on the regulatory conditions in the New Zealand market.

As noted above, other areas of law appear to be more important for incentivising foreign investment in the film and music industries. New Zealand's 'untouched' landscape is another relevant factor for the film industry. Indeed, if anything, strong performers' rights are likely to be a disincentive to invest in New Zealand, as investors (that is, producers) will want to negotiate away any rights that performers hold. ${ }^{127}$

The MED further noted that there did not seem to be any evidence that performers' rights or infringement thereof was an issue in New Zealand. ${ }^{128}$ As stated at the beginning of this chapter, there has never been a performers' rights case in New Zealand and, indicative of the general indifference to performers' rights, the MED only received 21 submissions in response to its Discussion Paper. None identified any substantial problem with the existing regime and very few supported any move for New Zealand to extend protection for performers, or to accede to the WPPT or an international agreement on audiovisual works. ${ }^{129}$ However, it is important to note that most of the submissions were from producers or users of performances. The few submissions from performers supported the extension of performers' rights. ${ }^{130}$

126 MFAT Trans-Pacific Partnership: National Interest Analysis (25 January 2016) at 90 [MFAT NIS].

127 Morgan, above n 8, at 49. See also Department of Justice Reform of the Copyright Act 1962 -

A Discussion Paper, above n 9, at 22.

128 MED, above n 11, at [26].

129 Office of the Associate Minister of Commerce, above n 19, at [12].

130 At [36]. 
Overall, reporting on the review, the Cabinet paper prepared by the Office of the Associate Minister of Commerce stated: ${ }^{131}$

There would appear to be no substantive benefit to New Zealand from making changes to the performers' rights regime at present. An extension of performers' rights would not necessarily result in increased or better performances, as performers appear to have a range of other incentives that encourage performance. These include incentives that are not primarily economic. Further, as New Zealand is a net importer of performances, any extensions to rights could simply flow overseas rather than to New Zealand.

As is common in the realm of intellectual property in New Zealand, the MED Discussion Paper and the report on the review often mention the need to be mindful of 'international developments' and changes made by other like jurisdictions. However, the conclusion wrought represents one of a few examples of New Zealand deciding not to follow these 'international developments', instead opting to retain the status quo.

In 2016, having signed the TPP, New Zealand had no choice but to start implementing 'stronger' performers' rights. Nevertheless, MBIE's RIS was consistent with the MED's reservations and stated that its objectives were: to keep amendments to the minimum required to meet TPP and WPPT requirements; to ensure that the correct balance is met between performers and producers, and performers and users; and to minimise any regulatory and business compliance costs introduced. ${ }^{132}$ It is correct to be wary of extending performers' rights more than is necessary. As noted by the MED in 2001: ${ }^{133}$

There have been no studies conducted in New Zealand on the economic consequences of extended performers' rights. Studies in Australia and Canada however, suggest that extended performers' rights may act as disincentives to the production of performances.

131 At [4].

132 MBIE RIS, above n 26, at [262].

133 MED, above n 11, at [119] (emphasis added), citing Steven Globerman and Mitchell P Rothman Copyright Revision Studies: An Economic Analysis of a Performers' Rights (Canadian Bureau of Consumer and Corporate Affairs, Ottawa, 1981); and Australian Federal Bureau of Transport and Communications Economic Effects of Extended Performers' Rights - Paper prepared for the Department of Communications and the Arts (Department of Communications and the Arts, Canberra, 1996). 
Fifteen years later, MFAT made a similar statement. In explaining why the new provisions only apply to aural and not visual aspects of performances, MFAT noted: 'It has not been established that going beyond TPP and WPPT obligations would result in a net benefit to New Zealand.'134 The reservations indicated by the MED, MBIE and MFAT should be commended, as recent years have seen New Zealand roll full steam ahead with broadening and strengthening certain areas of intellectual property, despite the similar lack of economic studies on the particular situation in New Zealand. ${ }^{135}$ This is not to say that broadening performers' rights could not be an overall boon for New Zealand, but rather that we cannot presume this until there has been a full economic investigation into the matter.

\subsection{Performers Rights and Moral Rights in Common-Law Countries}

A note should be made regarding the general apathy towards performers' rights and moral rights in common-law countries. New Zealand did not have either until it enacted the Copyright Act 1994. ${ }^{136}$ This is, of course, connected to the history of copyright law in England, which was about protecting publishers and copying. It was not really about authors and it most certainly was not about performers. Copyright has always been based more in utilitarian or law and economics theory. In comparison, performers' rights and moral rights have a strong history in Central Europe, where natural rights philosophies dominate. ${ }^{137}$ France's droit d'auteur (or author's right) has, thus, always been author-centric, as its name suggests, and civil-law jurisdictions tend to have robust moral rights. Similarly, France has a separate droit des artistes-interprètes (performers' right).

The historical and philosophical differences continue to create divergences today. Even though many common-law countries now have moral rights, they are seldom used or held out as an integral part of copyright law. Similarly, there are few cases on performers' rights in the United Kingdom,

134 MFAT Departmental Report, above n 29, Annex A at 70.

135 For example, regulatory data exclusivity and patent term extension. See Susy Frankel and Jessica C Lai, Patent Law and Policy (LexisNexis, Wellington, 2016) at ch 10.

136 This is despite the fact that New Zealand has been a Party to the WIPO Berne Convention for the Protection of Literary and Artistic Works, 828 UNTS 222 (adopted on 9 September 1886), since 1928. 137 See above $\mathrm{n} 4$. 
none in New Zealand, and - as the discussion above indicates - little interest in further developing performers' rights. This reflects a continued understanding of a hierarchy of creative beings, with the romantic author on top and the lowly performer clearly below. Indeed, the differentiation between performers on sound recordings in comparison to performers of film or audiovisual works reflects a further demarcation in hierarchy, with the musician or composer sitting higher than the actor or dancer.

The differences between the two legal systems plays out in a subtler way, which impacts performers rights. This relates to the standard of originality. The standard is very low in common-law jurisdictions, New Zealand included. In contrast, it is famously higher in civil-law jurisdictions, where it typically requires that there be an imprint of the author's personality. ${ }^{138}$ Because common-law jurisdictions have such a low standard of originality, performers can sometimes be authors or co-authors and, to a degree, a performance can constitute a work. This being the case, performers' rights are arguably of less relevance in common-law countries than in civil-law jurisdictions. ${ }^{139}$

\subsection{Performers as Authors/Performances as Works?}

Copyright envisages the traditional composer, playwright or choreographer as a lone creature, who is singularly the creative genius behind any given work. Copyright has a clear delineation between the author and the performer. However, in reality, there is no fine line between the two. It is hard to imagine that there ever was. Instead, performers often bring something more than just performance skills. They often rearrange music, adapt music, or change lyrics; actors often ad lib or improvise many of their lines. This can make them authors of rearrangements, co-authors of musical, literary or dramatic works, if the additions or rearrangements reach the required level of originality. Keeping in mind that the level of

138 Note, however, that there is 'an unstoppable trend towards a more objective criterion of originality'; Ramón Casas Vallés 'The Requirement of Originality' in Estelle Derclaye (ed) Research Handbook on the Future of EU Copyright (Edward Elgar, Cheltenham, 2009) 102-132 at 112. Moreover, although differences between copyright and droit d'auteur may not have entirely disappeared, interpretations of originality are converging (at 113). See also Sam Ricketson and Jane C Ginsburg International Copyright and Neighbouring Rights: The Berne Convention and Beyond (2nd ed, Oxford University Press, Oxford 2006) at para 8.05. For a comparison of the two traditions see the seminal study by Alain Strowel Droit d'auteur et copyright: Divergences et convergences. Etude de droit compare (Bruxelles, Bruylant, 1993).

139 One could speculate that performers' rights are more important in jurisdictions with higher standards of originality because it is very difficult for performers to be authors. 
originality required in common-law countries is low, it might commonly be the case that performers have copyright, but as authors rather than as performers. ${ }^{140}$

As far as the author is aware, New Zealand does not have any case law on the matter. However, United Kingdom case law is highly illustrative of the general trend of copyright expanding its understanding of the author. In Brooker $v$ Fisher, ${ }^{141}$ the England and Wales Court of Appeal held that Mr Fisher, an organist who improvised changes to Mr Brooker's composition during rehearsal, which were later recorded, was a co-author of the rearrangement. Mr Brooker was the author of the original musical work. What was eventually recorded was a rearrangement made by Mr Fisher, who was deemed to be a co-author of the rearrangement. Two things should be noted. First, Mr Brooker was the 'traditional' composer. He composed the music and lyrics, before putting a band together to perform his works. In contrast, Mr Fisher composed via performance. The corollary to a performer being an author through performance is that performance can define the work. Second, the fixation of $\mathrm{Mr}$ Fisher's work was via sound recording, not writing. Fixation via non-written means is specifically allowed in New Zealand, for works and rearrangements, and can be 'in writing or otherwise'. ${ }^{142}$ When fixation is via sound or film, the question arises of what exactly the work encompasses.

The bounds of the 'musical work' or 'dramatic work' are by no means clearly defined. In Coffey $v$ Warner/Chappell Music Ltd, ${ }^{143}$ the England and Wales High Court was quick to hold that the following were interpretation or performance characteristics by the performer, which is not the legitimate subject of copyright protection in the case of a musical work: ${ }^{144}$

The claim, as now formulated, is that the recording of Forever After 'includes an original musical work comprising the combination of vocal expression, pitch contour and syncopation of or around the words "does it really matter"' [emphasis added]. She refers to this as 'the Work'.

140 This has been the case in the United Kingdom, see Bamgboye $v$ Reed (2002) EWHC 2922; and Brooker v Fisher [2008] EWCA Civ 287. See Luke McDonagh 'Rearranging the Roles of the Performer and the Composer in the Music Industry - the Potential Significance of Fisher v Brooker' (2012) 1 IPQ 64 at 68-70 and 75-76; and O'Connor, above n 96.

141 Brooker v Fisher [2008] EWCA Civ 287.

142 Copyright Act 1994, ss 15 and 34(2).

143 Coffey $v$ Warner/Chappell Music Ltd [2005] EWHC 449 (Ch).

144 At [4]-[5] and [11]. 
By 'voice expression' is meant, in effect, 'timbre' (illustrated by a comparison between the 'gravelly' vocal expression of one well known performer and the 'twangy' vocal expression of another). By 'pitch contour' is meant 'the general shape of the pitches to which the words "does it really matter" [in Forever After] are sung' rather than, as I understood it, the notes themselves. By 'syncopation of or around the words "does it really matter"' is meant the 'unnatural metrical stress' given to the syllables of those four words 'in terms of their placement within the two bars [in which they are sung] and the unusual rhythmic and durational stress in terms of their elongated durations'.

The Court was clear that aspects of performance are not the subject of copyright protection. However, the problem was possibly more that the plaintiff used language that was simply too clear about performance. Perhaps, had the plaintiff used copyright-acceptable language, her case might have been stronger. To illustrate the point, in Hyperion $v$ Sawkins, ${ }^{145}$ what the England and Wales Court of Appeal accepted as forming part of the musical work included aspects that were very performance-based. Regarding 'performing editions' that Dr Sawkins had recreated from outof-copyright music by Michel-Richard de Lalande, Mummery LJ stated: ${ }^{146}$

Hyperion's arguments ignore the fact that the totality of the sounds produced by the musicians are affected, or potentially affected, by the information inserted in the performing editions produced by Dr Sawkins. The sound on the $\mathrm{CD}$ is not just that of the musicians playing music composed by Lalande. In order to produce the sounds the musicians played from Dr Sawkins' scores of his edition.

His Honour continued: ${ }^{147}$

It is wrong in principle to single out the notes as uniquely significant for copyright purposes and to proceed to deny copyright to the other elements that make some contribution to the sound of the music when performed, such as performing indications, tempo and performance practice indicators, if they are the product of a person's effort, skill and time ...

In essence, the Court held that all the instructions for performance written down by Dr Sawkins in his performing editions (piano/forte/fortissimo, adagio/allegro/allegrissimo, gentile/furioso, for example) were part of the musical works. But what if a work is fixed by sound recording? What is 
then recorded as being part of the work? If a work is more than just the musical notes and their lengths, how do we know from a sound recording what the instructions for performance are that form part of the work?

In fact, Mummery LJ noted that: ${ }^{148}$

Music must be distinguished from the fact and form of its fixation as a record of a musical composition. The score is the traditional and convenient form of fixation of the music and conforms to the requirement that a copyright work must be recorded in some material form. But the fixation in the written score or on a record is not in itself the music in which copyright subsists. There is no reason why, for example, a recording of a person's spontaneous singing, whistling or humming or of improvisations of sounds by a group of people with or without musical instruments should not be regarded as 'music' for copyright purposes.

Of course, though fixation can be by writing or otherwise, this is not to say that a work fixed by sound recording must, thus, include more than just notes and words. Mummery LJ conflated substance with form.

All the same, the result is that some aspects of performance when recorded can constitute part of a copyright work. The question is which aspects of performance? For example, if performance instructions are part of a musical work, then a performer choosing to not follow those instructions might create a rearrangement. If recorded, the performer could then be the author of the rearrangement. ${ }^{149}$ No one else would be able to imitate the way that the rearranger played the piece, not even the author/owner or licensee of the original piece. The rearranger would essentially have copyright for the performance as a work.

The same issues arise with visual performances. Mummery LJ also noted: ${ }^{150}$

In principle, there is no reason for regarding the actual notes of music as the only matter covered by musical copyright, any more than, in the case of a dramatic work, only the words to be spoken by the actors are covered by dramatic copyright. Added stage directions may affect the performance of the play on the stage or on the screen and have an impact on the performance seen by the audience. Stage directions are as much part of a dramatic work as plot, character and dialogue.

148 At [53].

149 See Redwood Music v Chappell [1982] RPC 109 (QB), which held that even an unauthorised rearrangement can have copyright and the rearranger is the owner. However, there is infringement. 150 At [55]. 
But, if stage directions also constitute part of the dramatic work, what is the dramatic work when fixation is via film? Is not then every pause, stress on certain words, eyebrow raise or dramatic turn of the head, for example, a stage direction? And if one had a licence to perform the dramatic work, could one be liable for breach of the moral right to integrity of the work if one performed the words differently?

It is one thing to say that a musical work is more than the notes and their length, or that dramatic work is more that the words, but it is something else entirely to deal with the consequences of such a statement. One of the reasons why Dr Sawkin's performing instructions were considered part of the musical works is undoubtedly that they were in the correct form. That is, in a form that copyright accepts, written down on the score. In contrast, Ms Coffey used descriptive performance language. This is not to say the Ms Coffey had a valid case, but that she could have made a stronger case. Despite Mummery LJ's statement regarding nonwritten forms of fixation, it is hard to imagine that a court would be open to accepting aspects of performance as part of a copyright work when presented in a sound recording or film. ${ }^{151}$ This is, however, the logical next step from Hyperion $v$ Sawkins. ${ }^{152}$

If the trend is that performers can be authors and it seems that performances might become works, the question then arises of what we need performers' rights for. Copyright, after all, offers a broader system of protection, protecting something abstract and not individual embodiments. The answer to the question requires the recognition that very few performers reach the level of skill or success where they can create an original rearrangement or adaptation and be authors or co-authors. It is only lead actors, band members and named artists who have this potential. Such performers often have copyright anyway, because they are singer-songwriters or dabble as screenwriters, producers or film directors. The majority of performers are background actors, singers or dancers, sessional musicians or members of an orchestra, who would not have the opportunity to be authors via performance. It is perhaps these performers who require performers' rights.

151 The history of copyright stemming from the introduction of the print press, with sound recordings and films being relatively new categories of works, means that there is an inherent snobbery regarding the medium of fixation.

152 Hyperion $v$ Sawkins, above n 147. 
It is worth noting that performers who do not bring 'something more' to become authors of rearrangements or derivative works, or co-authors of copyright, are not less deserving of performers' rights. First, unlike copyright, performers' rights are devoid of any assessment based on quality. The action of performance alone equates to subsistence. Second, even if a performer does not do anything that qualifies as 'original' in the copyright sense, this is not to say that they do not bring something worthy of protection. Members of symphony orchestras are illustrative; they follow the score before them and the instructions of the maestro, but it would be ungenerous and untrue to say that they are not highly skilled and do not bring something to the table, possibly even something indescribable.

\subsection{Commercial Reality}

Economic situations change. Fifteen years passed between the MED review and MBIE's RIS. ${ }^{153}$ It is possible that much had altered in this period and perhaps New Zealand had since become ripe for 'stronger' performers' rights, particularly with respect to the majority of performers - that is, those who do not have 'star power' or who do not have the opportunity to create original works. The film industry in 2017 is not the same as the film industry of 2001 . This is not only because of international blockbusters like the 'Lord of the Rings' and 'The Hobbit' movies, ${ }^{154}$ but also the impact of local films and television, such as 'Boy' and 'Hunt for the Wilderpeople'. ${ }^{155}$ Similarly, the music industry has developed significantly, with many artists having international repute, such as Lorde and Brooke Fraser.

Furthermore, technology changes. As information and communication technologies have affected the realm of copyright, these technologies arguably also affect performers' rights. For example, one could argue that the increased ease with which one can record and distribute

153 MED, above n 11; MBIE RIS, above n 26.

154 Peter Jackson (dir) 'The Lord of the Rings: The Fellowship of the Ring' (2001); Peter Jackson (dir) 'The Lord of the Rings: The Two Towers' (2002); Peter Jackson (dir) 'The Lord of the Rings: The Return of the King' (2003); Peter Jackson (dir) 'The Hobbit: An Unexpected Journey' (2012); Peter Jackson (dir) 'The Hobbit: The Desolation of Smaug' (2013); Peter Jackson (dir) 'The Hobbit: The Battle of the Five Armies' (2014).

155 Taika Waititi (dir) 'Boy’ (2010); Taika Waititi (dir) 'Hunt for the Wilderpeople’ (2016). 
performances might justify stronger performers' rights and also some level of harmonisation of such to allow for international protection and enforcement. ${ }^{156}$

Still, given the contractual nature of the relationship between performers and producers, it is questionable whether modifications to performers' rights will result in any concrete changes to these contracts and the reality of New Zealand performers (or performers anywhere). The Copyright Act 1994 states that a person who has recording rights may bring an action of infringement on behalf of the performer, without their consent (unless the performer expressly requires that consent be obtained). ${ }^{157} \mathrm{~A}$ person having recording rights includes a person (or his/her assignee) with an exclusive recording contract, or someone authorised by that person (or his/her assignee) to make recordings or copies of recordings for the purpose of commercial exploitation. ${ }^{158}$ One can infer from this that performers can contract around their rights, even though they are personal rights and not property rights in the Copyright Act $1994 .{ }^{159}$ As a result, performers can, in effect, assign away their rights by exclusively contracting broad consent; for example, an exclusive recording contract, including the exclusive right to communicate and copy the recording for any purpose.

If the relationship between performers and producers is dominated by contract law, giving performers property rights will not change their situation, as it does not affect their bargaining power. At the end of the day, the bargaining power of any artist will depend on his or her reputation and the market demand for that artist, and also the relative bargaining power of the producer. That is, while performers with star power, who tend to be copyright authors/owners anyway (because they are authors or co-authors, whether in a classical sense or via performance), can essentially demand the contracts that they want; performers with less star power achieve less favourable contractual terms. This is not affected by performers' rights, regardless of whether they are personal rights or property rights.

156 There is very little research on the impact of digital technologies on the performing arts. For a survey of the existing literature, see Ruth Towse 'Performing Arts' in Ruth Towse and Christian Handke (eds) Handbook on the Digital Creative Economy (Edward Elgar, Cheltenham, 2014) 311.

157 Copyright Act 1994, s 196(2). Compare CDPA 1988 (UK), ss 185-188, which is much more explicit about exclusive recording rights than the Copyright Act 1994.

158 Copyright Act 1994, s 169.

159 Copyright Act 1994. 
As the Department of Justice noted in 1989, before New Zealand had any performers' rights, 'it is open to a performer to obtain such rights by contract with a record or film maker'. ${ }^{160}$ The Department of Justice was, thereby, acknowledging that performers with enough bargaining power would be able to demand performers' rights in their contracts. Of course, one requires something to bargain around, which may be some kind of performers' rights, but might also be the simple ability to decide whether or not one is willing to perform. The primacy of contract law over any performers' rights is also reflected by the fact that featured artists usually have individual contracts, stipulating any fixed payment plus royalty rates for box office or CD sales, for example, whereas backing singers and musicians (non-featured or session musicians) and extras tend to be paid a flat rate, one-off payment.

As an illustration, New Zealand has no right to equitable remuneration for performers, nor will it if it implements the CPTPP. ${ }^{161}$ Nevertheless, Recorded Music NZ exists, which collects certain licensing revenues for performers of sound recordings. ${ }^{162}$ It is obvious from the discussion above that producers are under no statutory obligation to share their licensing revenues with performers. Recording Music NZ collects revenues from producers who opt to share their licensing revenues, from public performance and communication of the sound recording, with performers, splitting the revenues 50:50. ${ }^{163}$ This requires that both the producer and the performer register with Recorded Music NZ. This relationship may arise through contract. In other words, a performer with a strong balance of power might insist that his/her contract include a provision requiring that both producer and performer be registered with Recorded

160 Department of Justice Reform of the Copyright Act 1962 - A Discussion Paper, above n 9, at 22. See also Department of Justice The Copyright Act 1962 - Options for Reform, above n 9, at [10.8]-[10.9]. 161 See above n 62.

162 This paragraph is based on an email from Dean Cameron (Distribution \& Member Services Manager) to the author regarding 'RMNZ / Performer Rights' (10 October 2016). Recorded Music $\mathrm{NZ}$ manages the rights of sound recording right holders, namely recording artists and recording labels. It was previously known as PPNZ Music Licensing. PPNZ was established in 1957 under the name Phonographic Performances (NZ) Limited.

163 Recorded Music NZ does not itself collect revenues, but works together with the Australasian Performing Right Association Limited, Australasian Mechanical Copyright Owners Society Limited (APRA AMCOS), Australia and New Zealand's main (but not only) collecting society for performing and mechanical rights. APRA AMCOS manages the rights of songwriters, composers and music publishers. Recorded Music NZ has a joint licensing initiative with APRA AMCOS, offering a 'OneMusic licence' for all public performance licensing, offering a single music licence covering performing rights (but not mechanical rights) and sound recording rights. On APRA AMCOS, see Susy Frankel Intellectual Property in New Zealand (LexisNexis, Wellington, 2011) at 182-184. 
Music NZ and that the licensing revenues be shared accordingly. As at 10 October 2016, around 2,500 artists were registered with Recorded Music NZ. At the same time, if New Zealand were to implement 'stronger' performers' rights, artists with less bargaining power will nevertheless end up contracting away their rights. It will still be performers with enough bargaining power and producers who are more open to sharing their royalties that register with Recording Music NZ.

A way to overcome imbalances in bargaining strength is via the introduction of non-waivable, non-alienable rights to equitable remuneration, which tend to be collectively managed. ${ }^{164}$ This is an entitlement protected by a liability rule rather than a property rule. ${ }^{165}$ Rights to equitable remuneration are often considered to be 'lesser' rights, compared to rights to exclude. However, in cases where the right holder is in a weak bargaining position, such rights are arguably 'greater' as they cannot be negotiated away as a consequence of an imbalance of bargaining power. Put another way, rights to exclude are not stronger rights in practice if they can be easily bargained away. Indeed, as noted by Towse, regarding performers in the United Kingdom and a right to equitable remuneration for sound recordings compared to assignable individual exclusive rights, ${ }^{166}$ the latter might not change anything for performers, or might in fact decrease the bargaining power and income of performers. This is because contracts will either continue to be standardised or individual negotiation will result in performers being undercut because the market is overcrowded with performers. ${ }^{167}$ This perspective is supported by the fact that the Musicians Union (MU) in the United Kingdom achieved a great deal for its members, including royalties for mechanical reproduction of records,

164 See above n 62.

165 See Guido Calabresi and A Douglas Melamed 'Property Rules, Liability Rules, and Inalienability: One View of the Cathedral' (1972) 85(6) Harv L Rev 1089. As a response to Calabresi and Melamed's article, Epstein has argued that property rights should dominate because most things do not have a cash-value equivalent and liability rules create instability or a destabilising of possession, expectations and transactions; Richard A Epstein 'A Clear View of the Cathedral: The Dominance of Property Rules' (1997) 106 Yale LJ 2091.

166 In 1996, performers of sound recordings were given the right to 'equitable remuneration' if the performance was played in public, communicated to the public or made available to the public; CDPA 1988 (UK), s 182D, as amended 1 December 1996 by The Copyright and Related Rights Regulations 1996 (SI 1996/2967). The same Regulations introduced the individual property rights for performers (ss 183A-182CA). The United Kingdom now has the Performing Artists Media Rights Association (PAMRA), which is the largest collecting society for performers of music in the United Kingdom.

167 Towse, above n 84, at 758 (emphasis added). 
despite the lack of performers' rights throughout the 20th century. ${ }^{168}$ Private agreements between record companies and the MU additionally gave the latter some control over third party use of records, as the MU required that the record companies restricted certain uses in public places by licence. ${ }^{169}$ Thus, the role of contracts remains crucial and arguably central.

Furthermore, introducing individual assignable property rights could make non-star performers vulnerable, as the removal of collective bargaining could lead to producers taking a 'divide and rule' approach. ${ }^{170}$ Given that most performers are not superstars, it is likely that 'stronger' individualised performers' rights are unlikely to benefit most (if any) performers. It would likely be more advantageous for the majority to work as a collective, whereas it likely makes no difference for the minority superstars, who benefit from strong bargaining power in any case.

Common-law countries are generally wary of liability rules, including non-waivable rights to adequate remuneration. The concept is, however, widespread and accepted in Central Europe, which often connects the liability rule with compulsory collective management. ${ }^{171}$ Large collecting societies have significant bargaining power, which is important for the artists that they represent. New Zealand has essentially introduced a very Central European subject matter (performers' rights), but has attempted to do it in a common-law manner (with no liability rules). The result is less than convincing.

The introduction of moral rights for performers is arguably of equally little practical consequence. This is because moral rights can be waived and this is standard in industry contracts between performers and producers of sound recordings and films. However, the waivers are only valid between the performers and copyright owners, meaning that performers would still

168 Williamson, above n 116 , at 177-178.

169 Williamson, above n 116, at 178-179. This was in an agreement between the Musicians Union and Phonographic Performance LTD (PLL), which consisted of EMI and Decca.

170 Towse, above n 84, at 758-759.

171 The author-centric system in Central Europe has many more rights that cannot be waived or transferred. The end effect of this can be that collective management is the only viable means to enforce copyright or for authors to be remunerated for the use of their works with respect to certain rights. Consequently, Continental Europe has also developed many copyright rights that are remuneration-based, many of which are subject to compulsory collective management. On collective management, see Mihály Ficsor Collective Rights Management of Copyright and Related Rights (WIPO, Geneva, 2002); and Daniel Gervais (ed) Collective Management of Copyright and Related Rights (Kluwer Law, Alphen aan den Rijn, 2010). 
have moral rights against third parties. Furthermore, as with economic rights, performers with more bargaining power will be able to retain any introduced moral rights.

The relative subordinate nature of performers' economic and moral rights next to contract law was acknowledged by MFAT in its National Interest Analysis, which stated: ${ }^{172}$

While performers would be given new rights over the copying and distribution of recordings of their performances, the potential impact of these new rights may be limited in practice. This is because performers would be able to assign their rights to third parties....

In practice New Zealand performers already receive royalties for rights connected to their performance through contractual arrangements and it is not clear that the flow of royalties would be likely to increase to any significant degree.

The new rights for performers may benefit some New Zealand performers. It could give some better bargaining power when entering into recording contracts. However, this is unlikely to significantly change the bargaining dynamics or substantive outcomes of contracts between performers and the producers of sound recordings in most cases.

In other words, the impact of the new rights would be minimal, because the resultant position of performers would continue to be ruled by contracts between performers and producers. Giving performers 'stronger' rights in the form of property rights would not affect their bargaining power.

In essence, one can view the introduction of property rights that can be assigned away from two perspectives: (1) a genuine but ineffectual attempt to give performers greater protection; or (2) an intentionally ineffectual implementation of international law, to keep down costs for users, knowing that contract law and bargaining power will dominate. New Zealand has clearly opted for the latter. 


\section{Final Thoughts}

Regardless of whether the CPTPP comes into force, New Zealand will likely have to introduce 'stronger' performers' rights for sound recordings at some point, making them definitively property and not personal rights, and giving performers moral rights over their performances. It is not in question whether performers deserve rights in comparison to authors. It is quite clear that the conceptualisation of the 'romantic author' next to the 'lowly performer' is dated and simply incorrect. It is, however, debatable how any given jurisdiction can best protect performers, in the sense of creating a conducive atmosphere for creativity via performance. Whether neighbouring rights are the correct method is dubious.

Case law from the United Kingdom indicates that performers can have copyright when they rearrange or modify a musical work enough that they overcome the standard of originality. Given the similarities between the categories of works in the United Kingdom and New Zealand, and the low standard of originality in New Zealand, it is likely also the case in New Zealand that performers can be authors. If performers can be authors, they do not need performers' rights.

Not all performers are, however, in the position to be authors. One could, thus, conclude that performers' rights are important for less creative performers - those who do not bring anything original in the copyright sense. However, the most important factor for such performers will not be the strength of performers' rights, but the reputation and demand for a performer and, thereby, that performer's bargaining power and ability to negotiate a favourable contract, whether in relation to a music producer, venue owner or broadcaster. The introduction of assignable and waivable rights (as per the TPP Agreement Amendment Act 2016) does not change this. One has to have some rights as a performer, but the stronger one's bargaining power, the fewer rights are required. For example, Beyoncé probably does not require any more than primary rights. If one is not allowed to record her without her consent or to transmit her live performances, she already has a lot to bargain with vis-à-vis record companies and venues, and to control the use of her performances. With her bargaining power, Beyoncé could negotiate terms of contract regarding reproduction, distribution and royalties, regardless of whether she has those rights under law. 
Performers' rights should, hence, be geared towards performers who do not have the opportunity to create original works and who do not have 'star power'. What one must acknowledge is that the idea that 'stronger' rights - that is, property rights - equate to improving a performer's position is mistaken. Introducing 'stronger' rights that can easily be signed away does not change the imbalance of bargaining power that most performers face. The question then arises of whether a liability rule would, in effect, be more conducive towards supporting performative creativity.

While this chapter has predominantly dealt with the New Zealand situation, several of its conclusions apply equally to the Asian Pacific region. Namely, the conclusions about the comparative creativity of authors compared to performers, and the importance of contract law and relative bargaining power. Moreover, most Asian Pacific nations do not have a history steeped in Central European natural rights theory, including those that have civil-law systems. Instead, copyright and neighbouring rights are, typically, either artefacts of colonialism or a result of international trade agreements. If the Asian Pacific region is to take a particular perspective on performers' rights, different from that embodied in the WPPT, and codify this, it should allow for a system that fits its various cultures and commercial realities.

Taking a step back, there is a key question that has yet to be answered: why should the Asian Pacific region harmonise (to any degree) performers' rights beyond its WPPT obligations? So long as nations are aware of the relationship between performers' rights and contractual bargaining power, and act accordingly to meet their policy aims, it might be in the region's interest to stick with the WPPT and its flexibility. 
This text is taken from Making Copyright Work for the Asian Pacific: Juxtaposing Harmonisation with Flexibility, edited by Susan Corbett and Jessica C Lai, published 2018 by ANU Press, The Australian National University, Canberra, Australia.

doi.org/10.22459/MCWAP.10.2018.09 